\title{
Overcoming Aural Proficiency: Pitfalls for Heritage Learners in Russian Cyberspace
}

\author{
Donald Loewen, Binghamton University
}

\begin{abstract}
Heritage language learners soon learn that their verbal competence can be both a blessing and a burden. Reliance on aural cues can provide significant interference in attempts to master spelling conventions. Now, an unlikely source - the Russian-language internet threatens to provide negative reinforcement for the very spelling habits that instructors want to correct. This article is an attempt to introduce the emerging phenomenon of "earspelling" in the Russian internet and to identify how these developments may affect heritage learners.
\end{abstract}

\section{Introduction}

Heritage learners typically begin formal language study with a significant amount of verbal competence. When enrollment realities have left me with an intermediate language class that includes both heritage and non-heritage learners, the non-heritage group can feel threatened by this competence: Will they be expected to match the heritage learners by performing at the same level in speaking and listening exercises? ${ }^{1}$ Soon, each group starts to recognize that the linguistic playing field is more level than they first suspected, and heritage students find themselves in an unexpected situation: their verbal competence can be both a blessing and a burden. If they want to write proper Russian, they will need to overcome the temptation to rely on their verbal skills when spelling. Reliance on aural cues will prevent success. Now, an unlikely source - the Russian-language internet threatens to provide negative reinforcement for the very spelling habits that instructors want to correct. This article is an attempt to introduce the emerging phenomenon of "earspelling" in the Russian internet, and to identify how these developments may affect heritage learners in particular, but other students as well. But the ramifications of earspelling do not stop there. Given the constantly increasing importance of the web in all areas of life, including education, the linguistic developments in Russian cyberspace have the potential to affect everyone who uses the Russian internet.

\section{Reading and Research for Language Learning}

Extensive use of reading activities is one key strategy to help students improve their writing. Reading good Russian prose provides model constructions and more authentic usage than heritage learners are typically exposed to in their peer groups. In addition, reading activities provide ideal opportunities to increase the culture quotient of a language course. From Pushkin's poetry to Zoshchenko's prose, reading classic Russian literature opens these students' eyes to their rich linguistic and cultural heritage.

But we don't want our students to stop there. Many of their families left Russia (or Ukraine, or Kazakhstan, etc.) when the USSR still existed, and we want to facilitate a more current encounter with Russian texts and Russian culture. If we can connect them to a topic that 
captures their interest, there is frequently a dramatic increase in student motivation and satisfaction. I have frequently had heritage speakers select a topic that interests them in current Russian cultural, political or entertainment news and then present a written analysis for me and an extemporaneous oral summary for their classmates. We all learn something from the projects.

Of course, the modern research medium of choice for these assignments is the internet. It provides immediate access to media outlets and cultural sites in Russia, and students already understand the technology. I provide links to important Russian internet resources on my course website but typically students just use these as staging areas for their own wide-ranging exploration. Until recently, I considered the standard academic "internet warnings" adequate when advising students for these assignments. Now, however, a new danger lurks on many of Russia's internet pages, something that seems to provide direct negative reinforcement for heritage students in an area where they already face significant challenges: spelling.

\section{Alternative Spelling and Language Usage on Russian Web Pages}

Had it not been for a series of my own unplanned internet clicks, I might never have recognized the potential problem. I was reading about recent political developments in Moscow, and decided to visit one of the related discussion forums. Some of the posts caught my attention not only for their irreverent approach to politics, but also for their unusual orthography. Further tracking led to the wildly popular Russian section of LiveJournal.com, a site that offers anyone the opportunity to create a personal online diary and initiate or participate in various discussions.

Suddenly I started to see words and phrases that looked out of place, yet strangely familiar: адназначна [adnaznačna], for standard-Russian однозначно [odnoznačno] ('synonymous'); ничево в паследнее время [ničevo v paslednee vremja], for ничего в последнее время [ničego v poslednee vremja] ('nothing lately'), по ТВ щас такой фильм идет [ро TV ščas takojfil'm idet], for по ТВ сейчас такой фильм идет [ро TV sejčas takoj fil'm idet] ('there's this film showing on TV right now'). Not every entry contained these aberrations, but the number of posts and spelling - not grammar - mistakes suggested that the shift from standard usage was not due to ignorance or carelessness. I started to explore the way Živoj žurnal and the žižisty/žyžysty (i.e, the people who visit this site, from ЖЖ /ŽŽ, the common Russian abbreviation for LiveJournal) have started to change Russian cyberculture, and found a growing wave of unorthodoxy on one side of the linguistic spectrum, and increasing "literary angst" on the other side.

The spelling and writing changes have turned into a definite cultural marker on sites like LiveJournal. One Russian participant posted a tongue-in-cheek "diary" of his entry into the LJ world, and wrote about the need to update his vocabulary:

День 26. Изучал сленговую терминологию жижистов. Впечатлился словами "френдятник" и "лытдыбр"- по самые жабры. Сразу стали 
понятней другие дневники, зато домашние начали шарахаться от моего лексикона ("Plot", 2005).

[Den' 26. Izučal slengovuju terminologiju žižistov. Vpečatlilsja slovami "frendjatnik" $i$ "lytdybr" po samye žabry. Srazu stali ponjatnej drugie dnevniki, zato domašnie načali šaraxat'sja ot moego leksikona.']

(Day 26. I've studied the slang terminology of the žižisty. I was struck by the words "frendjatnik" and "lytdybr" all over the place. Suddenly all the other journals have become more intelligible, but at the same time the home folk have been taken aback by my vocabulary.)

Reading through movie reviews and social or political commentary on LiveJournal or other popular but decidedly more vulgar sites like Udaff.com (n.d.), one frequently encounters non-standard spelling that falls into several broad categories, and that closely resembles the spelling efforts by Russian heritage learners.

\section{Non-standard Spelling Patterns}

Both groups (the Russian "logo-clasts" and the heritage learners) show a patterned spelling shift that relies on aural cues, transcribing component sounds with the letters whose primary phonetic pronunciations matches these sounds. For the heritage learners, this is the natural first step in written communication. They "write the way they speak," as Chevalier (2004) puts it in an article on mastery of discourse register for heritage learners. At the most basic level, this means that students tend to associate a particular sound with a certain letter. Vowels, for instance, are associated with the way they sound when stressed. If a sound can be produced by two or more vowels, one when stressed and the others when unstressed, beginning heritage learners tend to transcribe the sound using the stressed vowel. The same principle holds for voiced and devoiced consonants. In numerous cases the transcription is not even based on a word's standard pronunciation, but on its pronunciation in more colloquial speech (e.g.сейчаc [sejčas] ('now') becomes [ $\check{s} \check{c} a s]$ or just $\left.\left[\check{s}^{\prime} a s\right]\right)$. These non-standard pronunciations are not new, of course, and the widespread use of colloquial (rather than literary) pronunciation has been studied in detail by linguists. ${ }^{3}$

Most significant is the strong similarity between the types of spelling mistakes made by the heritage learners and the native speakers, since both reflect a spelling based on aural cues rather than learned orthographic patterns. In the following tables I have listed a number of these mistakes as they appeared in one short text posted on a Russian web site, and as they appeared in a writing assignment submitted by several intermediate level heritage learners. For convenience, I have grouped the types of mistakes into three broad categories:

- $\quad$ vowels (e.g. vowel reduction and violation of spelling rules)

- consonants (e.g. voicing/devoicing)

- colloquial speech 
Some words fall into multiple categories. The first table contains words excerpted from one 129-word paragraph on a Russian web site. ${ }^{4}$

Table 1. Aural Interference Category

\begin{tabular}{|c|c|c|c|}
\hline $\begin{array}{l}\text { Word(s) as used [transliteration] // Standard } \\
\text { spelling [transliteration] ('translation') }\end{array}$ & $\begin{array}{l}\text { Vowels } \\
\text { (e.g. vowel } \\
\text { reduction) }\end{array}$ & $\begin{array}{l}\text { Consonant } \\
\text { s (e.g. } \\
\text { voiced/uni } \\
\text { voiced) }\end{array}$ & $\begin{array}{l}\text { voiced/uni } \\
\text {-voiced) } \\
\text { Colloquial } \\
\text { speech }\end{array}$ \\
\hline чессна [čessna] // честно [čestno] ('honestly') & $* *$ & & $* *$ \\
\hline када $[k a d a] / /$ когда [kogda] ('when') & $* *$ & & $* *$ \\
\hline 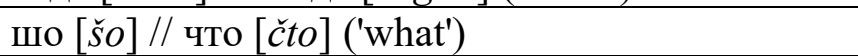 & & & $* *$ \\
\hline $\begin{array}{l}\text { в кинатиатре [v kinatiatre] // в кинотеатре }[v \\
\text { kinoteatre] ('at the movie theater' }\end{array}$ & $* *$ & & \\
\hline буит [buit] // будет [budet] 'will/will be' & $* *$ & & $* *$ \\
\hline пат [pat] // под [pod] ( 'under') & $* *$ & $* *$ & \\
\hline палицыя [palicyja] // полиция [policija] ('police') & $* *$ & & \\
\hline Тока [toka] // Только [tol'ko] ('only') & $* *$ & & \\
\hline $\begin{array}{l}\text { являюцца [javljajucca] // являются javljajutsja } \\
\text { ('appear/are') }\end{array}$ & & $* *$ & \\
\hline $\begin{array}{l}\text { немнога [nemnoga] // немного nemnogo ('a } \\
\text { little') }\end{array}$ & $* *$ & & \\
\hline $\begin{array}{l}\text { каторыми [katorymi] // которыми [kotorymi] } \\
\text { relative pronoun ('who/that/which' (instrumental } \\
\text { case)) }\end{array}$ & ** & & \\
\hline Хатя $[$ xatja] / (хотя) [xotja] ('although') & $* *$ & & \\
\hline $\begin{array}{l}\text { правелные [pravelnye] / (правильные) } \\
\text { [pravil'nye] ('correct') }\end{array}$ & $* *$ & & $* *$ \\
\hline
\end{tabular}

Anyone who has taught heritage learners will immediately recognize the type of spelling in Table 1. For comparison, Table 2 presents a sample of spellings taken from recent work by heritage learners. 
Table 2. Aural Interference Category: Non-standard Spellings from Course Work by Heritage Learners at an American University

\begin{tabular}{|c|c|c|c|}
\hline $\begin{array}{l}\text { Word(s) as used [transliteration] / } \\
\text { /(Standard spelling) [transliteration] } \\
\text { ('translation') }\end{array}$ & $\begin{array}{l}\text { Vowels }(\mathrm{e} . \mathrm{g} . \\
\text { vowel reduction) }\end{array}$ & $\begin{array}{l}\text { Consonants (e.g. } \\
\text { voiced/unvoiced) }\end{array}$ & $\begin{array}{l}\text { Colloquial } \\
\text { Speech }\end{array}$ \\
\hline $\begin{array}{l}\text { кабута [kabuta]// (как будто) [kak } \\
\text { budto] ('as if') }\end{array}$ & $* *$ & & $* *$ \\
\hline $\begin{array}{l}\text { несколго [neskolgo] // несколько } \\
{[\text { [neskol'ko] ('several') }}\end{array}$ & $* *$ & & $* *$ \\
\hline $\begin{array}{l}\text { штобы [štoby] // чтобы [čtoby] ('in } \\
\text { order to/so that') }\end{array}$ & & & $* *$ \\
\hline $\begin{array}{l}\text { пришол [prišol] // (пришёл) [prišel] } \\
\text { ('[he] arrived') }\end{array}$ & ** & & \\
\hline $\begin{array}{l}\text { тритсат [tritsat], тритсот [tritsot] // } \\
\text { тридцать [tridcat'] ('thirty') }\end{array}$ & ** & $* *$ & \\
\hline $\begin{array}{l}\text { нада [nada] // надо [nado] ('one } \\
\text { must/has to') }\end{array}$ & $* *$ & & \\
\hline $\begin{array}{l}\text { нащнётса [naščnetsa] // (начнётся) } \\
\text { načnetsja ('[it] will begin') }\end{array}$ & $* *$ & & $* *$ \\
\hline $\begin{array}{l}\text { севодня [sevodnja] // (сегодня) } \\
{[\text { segodnja] ('today') }}\end{array}$ & & $* *$ & \\
\hline фce [vse] // (все) [vse] ('all/everyone') & & ** & \\
\hline $\begin{array}{l}\text { шота }[\text { šota] // что-то [čto-to] } \\
\text { ('something') }\end{array}$ & $* *$ & $* *$ & ** \\
\hline $\begin{array}{l}\text { зделал [zdelal] / (сделал) [sdelal] } \\
\text { ('[he] did/made') }\end{array}$ & & $* *$ & \\
\hline $\begin{array}{l}\text { серовно [serovno] / (всё равно) }[v s e \\
\text { ravno] ('nevertheless') }\end{array}$ & $* *$ & & ** \\
\hline $\begin{array}{l}\text { чесов [česov], чисов [čisov] // } \\
\text { (часов) [časov] ('hours/clock/o'clock') }\end{array}$ & $* *$ & & \\
\hline $\begin{array}{l}\text { харошыи [xarošyi] // хороший } \\
\text { [xorošij] ('good') }\end{array}$ & ** & & \\
\hline щас [ščas] / сейчас [sejčas] ('now') & & & $* *$ \\
\hline каво [kavo] / кого [kogo] ('whom') & $* *$ & $* *$ & \\
\hline
\end{tabular}


The similarity between the two groups is unmistakable, and this awareness leads to important questions:

1) Why are some literate Russians embracing these spelling patterns?

2) How likely is it that our students will encounter these forms?

I will offer a brief response to both questions, but the phenomenon is still in its initial, and very active, development phase. The complex cultural, linguistic, sociological, even technological factors that are driving these changes can only be partially identified and analyzed at this time.

\section{Why the New Spelling?}

In the last fifteen years the Russian language has changed significantly. Two central contributing factors have been the influx of new (usually foreign-based) terms, and the rapid growth of new information technology. Many Russians struggle with the flood of new words. According to Olga Davydova, whose research at Moscow Open University focuses on new words and terms, "The contemporary language is meant for young people, those who adapt quickly and easily. The older generation frequently doesn't understand what people are saying to them in their own language. . . . To the elderly, it seems that they have fallen hopelessly behind, that they are superfluous." (Železnova \& Šengelija, 2005).

The principles that govern the "Russianization" of new terminology help to shed some light on the current spelling revolt. Linguists like Marian Wyjtwicz and V. M. Aristova agree that the medium through which a word migrates from another language into Russian has an important bearing on the way the new word will be written in Russian. Aristova traces the history of English-Russian interaction and notes several distinct eras. The first was characterized by verbal interaction and the Russian form of the English word was rendered phonetically, with multiple variants possible. In the second period the adoption of English words tended to be based more on their written forms, with some transliterations accompanied by a phonetic transcription in Cyrillic to guide pronunciation. The third period, Aristova says, has featured substantial contact in both oral and written form (Aristova 1978, pp. 43-45). Wyjtwicz's analysis offers examples of how these various paths tend to determine the Cyrillic renderings. The English word 'football', for example, entered Russian as футбол [futbol] based largely (but not entirely) on its phonetic structure, while the word 'bunker' (бункер) [bunker] depended primarily on a graphical representation. Words like 'tandem' can exist in multiple variants (тандем [tandem], тендем [tendem]) if both principles operate independently, while words like 'catgut' (кетгут) [ketgut] show that even individual phonemes of a single word can be rendered according to different principles (Wyjtwicz, 1984, pp. 25, 26-44). Terence Waight has examined the way Russianization works in oral speech and shows that pronunciation displays the same kind of fluidity as writing. Some speakers, notes Waight, will attempt to reproduce the sourcelanguage pronunciation even though it may violate fundamental Russian phonetic principles, but overall the adaptation of foreign words is heavily influenced by native morphological patterns. It is the words that are granted exception status that continue to be heavily marked as linguistically foreign, while others enter Russian in forms that are closer 
to typical Russian speech patterns and are naturalized much more readily (Waight, 1980, pp. 84, 86).

All of these assimilation patterns can be found in Russia's internet user community, which is exposed to a vast amount of new terminology in a variety of languages. Because of the nature of the internet, users must develop considerable facility in using the Latin alphabet and many develop a surprisingly robust English vocabulary. Many of these new words rapidly re-enter the Russian linguistic environment in Cyrillic form. Thus a žižist can write, completely unselfconsciously, a sentence like this: Обитатели комьюнити сначала долго смеялись, а потом объявили меня офтопиком. [obitateli kom'juniti snačala dolgo smejalis', a potom ob"javili menja oftopikom] (Plot, 2005). ('The inhabitants of the [ŽŽ] community first had a long laugh and then declared me an off-topic [person/writer]).'

Some writers will switch back to the Latin keyboard when writing individual foreign words, but most will simply transliterate the source word into Cyrillic and decline it where possible: комьюнити [kom'juniti] ('community') remains unchanged in the genitive case, while офтопик [oftopik] ('off-topic' [person/writer]) can easily be transformed to офтопиком [oftopikom] in the instrumental case. The pattern seems to favor what Aristova describes as the phonetic transformation pattern more than the graphical transformation pattern, where the sound of the word in the source language determines its written form in Russian. With so many foreign words now entering into Russian, and with writers' attention so focused on the relationship between sound and spelling, it is perhaps not surprising that writers would start to apply the same principles of phonetic translation to words in their native language. The same principle that renders business as бизнес [biznes] ('business') will want to render автор [avtor] ('author') as афтар [aftar] (or at least aфтор [aftor]), since it is based on a desire to harmonize the orthographic and the aural.

Significantly, the writing adaptations made by Russian internet users rarely violate grammar rules. These are not illiterate or even poorly educated writers, and meddling with the grammar would create active comprehension interference. As Fedor Smirnov notes:

We aren't talking about ignorant adolescents who have gotten the Web mixed up with the school bathroom, but precisely the opposite: at the center of attention is an association of counter-culture writers who express their views on various topics and receive almost instantaneous feedback from their reading public. The highest praise, on the order of awarding a literary prize, sounds something like this: 'Aftar, žžot! Peš̌i isčo!' ['Awther, this rocks! Write more!']

Criticism, reports Smirnov, can range from ultra-strong obscenities that need not appear here, to the stern but still decent Незачьёт! [Nezač'ot!] ('Failure/Failing grade') (Smirnov, 2005).

The developments within Russia's cyberculture are in many respects related to sociolinguistic changes observed worldwide with the growth of electronic communication, 
and linguists everywhere have taken note. In a 1998 article, American linguist Naomi Baron summarized linguists' questions about e-mail and other electronic communication this way: "Is email a variety of speech (as many people are claiming)? What important properties does it share with writing? Does it have emergent qualities that are unlike those typifying speech or writing?" One of the difficulties in analyzing the characteristics of writing in electronic forums, she notes, is that the nature of the medium makes it a "moving linguistic target" for linguists. Among other issues, she points out the complexity of trying to identify the sociolinguistic elements of electronic communication: the social expectations associated with electronic communication can vary widely from user to user, with some writers adopting a much more formal style while others prefer a much looser informality that expresses itself in unconventional orthography and grammar usage (Baron, 1998, pp. 134, 144, 155, 163-165; Collot \& Belmore, 1996, 13-28). Elena Butorina, a linguist at the Russian State Humanities University (RGGU), describes this mixed genre as "written colloquial speech, a peculiar mix of written literary and oral colloquial language." Authors have developed a system of abbreviations and symbols to push the emotional range of their writing closer to what they could achieve in oral communication, where gestures, intonation, and volume interact with a speaker's actual words. When these methods are employed within the internet's realm of abstraction (no instant feedback) and anonymity, an individual's internal sense of restraint tends to loosen, Butorina (2001) suggests.

As Baron, Butorina and others demonstrate, the electronic medium plays an important role in determining the speaker/writer's approach to communicating the message, and the phenomenon is not limited to Russian. English speakers are familiar with the relaxed spelling associated with e-mail messages, and other languages have noticed similar moves away from conventional spelling practices. Already in 1995 John Jensen noted emerging spelling changes in electronic Portuguese communication, prompted largely by the limitations of rendering Portuguese's frequent diacritics in a limited 7-bit ASCII character set. Users either abandoned the diacritics entirely and trusted that their readers would be able to reconstruct the words based on context or they developed various means of inserting other marks to function in lieu of the missing accents, cedillas, tremas and so on (Jensen, 1995, pp. 837-38).

In Russian, the recent linguistic changes are completely unrelated to the kinds of technological limitations that Jensen noted in 1995. Instead, sociocultural elements appear to be the dominant impetus. This came home to me most clearly when I unexpectedly encountered this linguistic revisionism on the Gramota.ru (n.d.) website, where Russia's leading linguists share the sophisticated results of their research on a variety of fascinating language-related topics that range from a discussion of the poor grammar and structure of the Duma's bill to safeguard proper Russian (Skvortsov, 2005) to a discussion of how Russian heritage learners can best master Russian in Israel (Vlasova-Kuric \& Kuric, 2005). Visitors can discuss scholarly articles, ask grammar- and language-related questions, and even post messages about poor Russian usage on radio and television broadcasts. Some questions initiate intense discussions, and while reading the wide range of opinions on the 
proper preposition ( $v$ ['in/at'] vs. $n a$ ['on/at']) to use before Ukraine, I was startled to come across the following post: ${ }^{5}$

Re: на Украине или в Украине? [na Ukraine ili v Ukraine?] ('at/on or in Ukraine?')

Автор: Ната [Nata]

Дата: 01-12-04 17:17

Помница, когда-то впервые едучи на Вкраину, внимательно внимала мамину совету: -- Едучи в иные области, перво-наперво надобно учить ихний язык. Первым твоим новым словом, пожалуй, будет

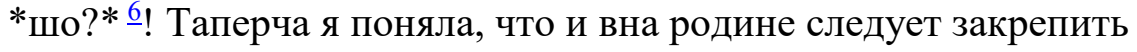
приобретенные навыки произношения.

[Pomnica, kogda-to vpervye eduči na Vkrainu, vnimatel'no vnimala maminu sovetu: -- Eduči v inye oblasti, pervo-napervo nadobno učit' ixnij jazyk. Pervym tvoim novym slovom, požalyj, budet *šo*? Taperča ja ponjala, čto $i$ vna rodine sleduet zakrepit' priobretennye navyki proiznošenija.

(Nata, 2004).]

('Re: na Ukraine or v Ukraine

Author: Nata

Date: $12 / 01 / 04$ 17:17

I recall going to Ukraine for the first time and carefully heeding my mother's advice: - When going to new places, the very first thing you have to do is learn their language. Your first new word is probably going to be *šo?* [what? in Ukrainian]! But now I realize that even in our own country we're expected to hold fast to such acquired habits of speech.')

Within the broader context of the discussion, this author's contribution could be viewed as at least partially facetious - but not entirely. Помница, [pomnica] ('one remembers') таперча [taperča] ('but now') and шо [̌̌o] ('what') are words completely unrelated to the specific focus of the discussion thread, and their usage here (instead of помнится [pomnitsja] ('one remembers') теперь-то [teper'-to] ('but now') and что [čto] ('what') is either an attempt to provoke the traditionalists, or an indication that the author routinely uses aural-determined spelling patterns in internet-based communication.

\section{How Widespread is the Phenomenon?}

It is not particularly surprising to notice non-standard spelling on "shock" sites like Udaff.com, where the flaunting of obscenity tends to make the spelling irregularities less noticeable. And the free-wheeling pages of LiveJournal.com engender a casualness that seems to invite abbreviation and the informality of creative spelling. But it comes as a surprise when even visitors to ultra-purist sites like Gramota.ru (n.d.), a site that staunchly defends standard literary Russian, start to communicate in a discourse that also utilizes non-standard spelling. Has this usage really traveled so broadly? 
Yes, it has, according to a May, 2005 article in Russkij Newsweek. Artem Vernidub reports that both Russian internet terminology and non-standard spellings are entering popular culture. He cites an April 29, 2005 demonstration against Belarus president Lukashenko in Moscow where protestors carried signs with slogans such as Лукашенко, выпей йаду [Lukašenko, vypej jadu] ('Lukashenko, take poison'), an expression modified from the internet expression of disapproval, афтар, выпей йаду [aftar, vypej jadu] ('Awther, take poison'). ${ }^{7}$ As Vernidub reports,

Not even all the demonstrators understood these slogans, because not everyone has learned the new rules of Russian thought up on the internet. But they will soon. While scholars were making timid efforts to replace the letter ю $[j u]$ with y $[u]$ in брошюра [brošjura] ('brochure') and парашют [parašjut] ('parachute'), a far more daring confluence of orthography and phonetics was taking place on the Web. (Vernidub, 2005).

One explanation for the ready acceptance of the new spelling is the appeal of texts that propagate it. "Of course, riff-raff creatives [i.e. texts] are mostly readings for dilettantes," writes Fedor Smirnov, "but there is something magnetic in the amusing way the typical story is woven together, in the language and world view of the author, that compels you to read many of the texts to the very end." (Smirnov, 2005). The irreverence appeals to many in the younger set of internet users who comprise the largest demographic grouping, and they, consciously or unconsciously, assimilate what they read until it emerges in their own writing and conversation. In a sense, the growing popularity of these terms in popular speech seems to show that the process noted by Professor Butorina also works in reverse: the "colloquial written" language can emerge from its electronic medium and enter popular verbal discourse.

As one might expect, some of those who object to the spread of "bad Russian" have organized opposition groups. One has called its campaign "I know how to speak Russian," and describes itself as "a campaign to defend the Russian language in LiveJournal. "Awther be an Author!" Supporters can adorn their web pages with banners and buttons that proclaim things like "I know how to speak Russian!", or "I want to read texts written in proper Russian!" (Ja umeju govorit' po-russki, n.d.). It is hard to know what effect a reactionary movement like this can have, but the level of popularity of the "real Russian" logos may indicate how many internet users share the anxiety about improper Russian. 


\section{Practical and Pedagogical Considerations}

Should knowledge of widespread irreverent spelling conventions discourage us from using Russian internet sources as a pedagogical tool for heritage learners? I don't think so. Many web sites still maintain rigorous language standards (at least in the material that they directly control - user forums are subject to fewer strictures). Even those that allow their users greater latitude in self-expression tend to feature a variety of language styles. As Smirnov puts it, "every author has an individual level of mockery for the Russian language." He cites one particularly extreme departure from spelling norms, and concludes: "To write a text like that is a lot more complicated than to observe all grammatical norms. The majority of the counter-culturists maintain a golden mean: reading a proper text is boring, but reading one distorted beyond all recognition is too hard." Smirnov suspects that much of the language distortion is like an April Fool's joke, just young people trying to provoke a reaction that will break up the tedium of internet interaction in a movement that may fade away on its own. ${ }^{8}$

Time will show whether this orthographic revolt is just a passing fancy and how much impact it will have in Russian culture. In the meantime, instructors should be aware that the Russian internet displays a much broader spectrum of language usage than one would find in print or broadcast media, and includes widespread usage that replicates almost exactly the fundamental mistakes that we are trying to help our heritage learners overcome. To help them, we can address the issues directly, and perhaps even assign them tasks that allow them latitude to explore, while also challenging them to identify improper usage and incorrect spelling.

One useful starting point for instructors is the identification of suitable web sites for students to use when completing web-based assignments or when taking their initial exploratory steps in the Russian internet. Instructors may want to find and post their own links to basic news and current events sites, or they may prefer to direct students to comprehensive and well-designed collections of links maintained by others. ${ }^{9}$ These sites provide a much-appreciated service for smaller programs like the one at my university, since keeping a collection of web links current can be a time-consuming and challenging prospect.

When it comes to specific assignments, though, instructors will likely want to find their own sites. For example, in my second year Russian class I recently prepared two webbased assignments. To accompany our textbook's unit on travel, I had students visit the web sites for Moscow's hotel Rossija (n.d.) and Suzdal's much smaller Горячие ключи [Gorjačie ključi] ('Hot keys') (2006). ${ }^{10}$ I asked students to browse the sites in preparation for an impromptu dialogue with a classmate in which they would discuss the relative advantages and disadvantages of each hotel and agree on how they would divide their time between the two during a visit to Russia. The combination of photos and familiar vocabulary allowed students to learn about various categories of Russian hotel rooms and restaurants, and about other amenities that might make their stay more enjoyable. The assignment worked well for both heritage and non-heritage learners, since students could borrow new terminology and useful expressions directly from these well-produced 
commercial web sites. Heritage students tended to have greater comprehension of the material, but all students were able to gain both new vocabulary and new cultural insights about Russia's tourist and hotel industries. My experience has been that this type of assignment will tend to keep most students engaged within the bounds of the two primary web sites. There is less inclination to venture further afield because the assignment doesn't encourage broader exploration, and using carefully chosen sites makes it unlikely that students will come across any of the maverick language usage described above.

The second assignment was quite different. This time the topic was Television and Movies, and I asked students to explore current movie listings and film synopses in the entertainment section of the popular Km.ru afiša (n.d.) site. ${ }^{11}$ The assignment had multiple stages, beginning with a browse through the listings to choose the Russian-made film that they would be most interested in seeing. Next, students wrote a brief summary of the plot and identified the director and principal actors. Finally, they prepared for impromptu dialogues in which each one explained why they were interested in their chosen movie and said a little bit about the theater where it was being shown. Once again I provided a link to the main site, but this time the students were confronted with a much more enticing array of peripheral links leading to other sites. Some led to descriptions of the intriguing attractions at Moscow's most exclusive movie theaters, while others were openly provocative links that redirected browsers to dubious sites with persistent pop-ups and other potentially disruptive elements. ${ }^{12}$ In some cases, a few quick clicks could lead them into forums where discussion of a film's relative merits might include some of the nonstandard language usage discussed in this article. This assignment offered students more self-directed choices, featured much less instructor control, and thus included a significantly higher likelihood that students would find themselves in uncharted cultural and linguistic territory.

If students do encounter some of the revisionist Russian during the course of their exploration, there are steps that instructors can take to address potential concerns. The first and most obvious step is to alert them that this phenomenon exists and seems to be spreading. Second, students can avoid inadvertently falling into the trap of merely replicating "internet spelling" mistakes in their own written work by putting technology to positive use. The Russian spell checkers available for today's word processing software offer one good way to monitor spelling and usage for typed assignments. Used carefully, spell checkers can become valuable assistants for writing. ${ }^{13}$ At the same time, students cannot become dependent on such software assistance, since handwritten work continues to be an integral part of Russian language learning. Rather than simply clicking "Accept" whenever a spell checker flags an offending word or phrase, students need to learn the principles that, for example, require reflexive verb endings to be spelled тся [tsja] even when they sound like ца $[\mathrm{ca}]$. While it may be tempting to gear web-based assignments towards the safer parameters outlined in my first sample assignment, I would be hesitant to eliminate the greater potential for individual exploration offered by the second assignment. If students find themselves confronted by the sociolinguistic turbulence of movie reviews on shock sites like Udaff.com (n.d.) (which provided the sample paragraph used in Table 1 above) or begin to explore the tamer discussions on a Russian blog site or 
forum, the experience can lead to useful class discussions about the nature of electronic communication and the relative similarities or differences between Russian and American internet culture.

It may even be worthwhile to deliberately point students to discussions on sites like LiveJournal and collaboratively read through several discussion threads. Besides the opportunity to discuss various cultural questions raised by the online discussions, students can be asked to observe and then discuss how grammar and spelling norms are observed or disrupted in selected posts. This type of exercise will work better for students with advanced comprehension, and would not really be suitable for intermediate students without some initial pre-screening by the instructor to find selections accessible to these students.

A direct discussion of the Russian internet phenomenon will also help to remind all of us that languages are dynamic organisms, and change with their users. Just as usage and spelling in English change (e.g. cheque becomes check), usage and even spelling can change in Russian as well. Is it possible that one day we will be the ones struggling to remember that we should write севодня [sevodnja] ('today') and not сегодня [segodnja]?

\section{Acknowledgement}

I would like to thank the HLJ's anonymous reviewers for their thoughtful and thoughtprovoking questions and comments, and would especially like to thank this issue's guest editor, David R. Andrews, for his advice and assistance.

\section{References}

Aristova, V. M. (1978). Anglo-russkie jazykovye kontakty: Anglizmy v russkom jazyke [Anglo-Russian language contact: Anglicisms in Russian]. Leningrad: Izd. Leningradskogo universiteta.

_a_c_e_. (2005, May 28). Ja vot čto podumal. LiveJournal. Retrieved November 7, 2006, from http://www.livejournal.com/users/_a_c_e_/ $/ 582038 . \mathrm{html}$.

Baron, N. S. (1996). Letters by phone or speech by other means: The linguistics of email. Language and Communication, 18(2), 133-170.

Butorina, E. (2001, January 26). A pogovorit'? Internet kak lingvističeskij fenomen.

Russkaja reč'. Retrieved November 7, 2006, from http://www.gramota.ru/rusrech.html?id=50.

Chevalier, J. F. Heritage language literacy: Theory and practice. Heritage Language Journal, 2(1), 2004. Available from www.heritagelanguages.org. 
Collot, M., \& Belmore, N. (1996). Electronic language: A new variety of English. In S. Herring (Ed.), Computer-mediated communication: Linguistic, social and crosscultural perspectives, pp. 13-28. Amsterdam: John Benjamins.

Gamma-del'ta. (n.d.) Turistskie gostiničnye kompleksy "Izmajlovo" [Izmajlovo Tourist hotel complexes]. Retrieved December 7, 2007, from http://www.izmailovo.ru/rus/.

Gostinica "Rossija," Moskva. (n.d.) Retrieved November 12, 2006, from http://www.hotelrossia.ru/.

Gostinica Akademičeskaja [Hotel Akademičeskaja]. (n.d.) Retrieved December 7, 2007, from http://akademicheskaya.bookin.ru.

Gramota.ru: Spravočnj-informacionnyj portal [Literacy: A reference-information portal]. (n.d.) Retrieved December 7, 2007, from http://www.gramota.ru.

Jensen, J. (1995). Writing Portugese electronically: Spontaneous spelling reform. Hispania, 78, 837-838.

KM.ru afisha. (n.d.). Retrieved November 12, 2006, from http://www.km.ru/entertainment.

Nata. (2004, December 1). Jazykovye ošibki na radio: narodnyj monitoring - na Ukraine ili v Ukraine? Gramota.ru. Retrieved November 7, 2006, from http://www.gramota.ru/forum/read.php?f=8\&i=1437\&t=1437.

"Fuckingtime." Otrjad Amerika/Vsemirnaja palicyija. (2005, February 7). Resurs Udava: Spešite videt'! Retrieved November 7, 2006, from http://udaff.com/movie/41069.html.

Ja umeju govorit po-russki! Akcija v zaščitu russkogo jazyka v (n.d.) Retrieved November 7, 2006, from http://tyv.name/action/.

Oficial'nyj sajt gostinicy Metropol' [Official site of the Hotel Metropol] . Retrieved December 7, 2007, from http://metropol-moscow.ru/ru.

Rekomenduetsja logopedami. (2004, October 29).Gorodovoj. Retrieved November 7, 2006, from http://www.gorodovoy.spb.ru/rus/news/culture/12250.shtml.

"Plot" (2005, May 27). Dnevnik ista. Apelsinforum. Retrieved November 7, 2006, at http://www.apelsinforum.ru/index.php?showtopic=796.

Re-art. (2006). Gostinično-turističeskij complex "Goriačie ključi." Retrieved November 12, 2006, from http://www.parilka.com/hotel/. 
Sher, B. (n.d.) Sher's Russian Index. Retrieved November 12, 2006, from http://www.websher.net/inx/icdefault1.htm.

Smirnov, Fedor. (2005, April 17). Aftar, pesši isčo! VebPlaneta. Retrieved November 7, 2006, from http://www.webplanet.ru/news/talks/2005/4/17/podonki.html.

Skvorcov, Lev. (2005, March 2). Jazyk moi. Čto rodila gora? Kommentarii k zakonu o russkom jazyke. Russkaja reč'. Retrieved November 7, 2006, from http://www.gramota.ru/rusrech.html?id=537.

Sun Microsystems. (n.d.) OpenOffice.org. Retrieved Dececember 19, 2007, from http://www.openoffice.org.

Udaff.com. (n.d.) Retrieved December 7, 2007, from http://www.udaff.com.

University of Wisconsin Center for Russia, East Europe, and Central Asia (CREECA). (n.d.). Country-Specific Links and Resources: Russian Federation) Retrieved November 12, 2006, from http://www.creeca.wisc.edu/resources/links/russia.html.

Vernidub, A. (2005). U jazyka est aftar. Russkij Newsweek 17. Retrieved November 7, 2006, from http://www.runewsweek.ru/theme/?tid=16\&rid=215.

Vlasova-Kurits, N., \& Kurits, S. (2005, May 6). O programme soxranenija russkogo jazyka $\mathrm{u}$ detej russkojazyčnyx roditelej, živuščix vne Rossii. Russkaja reč'. Retrieved November 6, 2006, from http://www.gramota.ru/mag_arch.html?id=527.

Waight, T. (1980). On the Phonology of Words of Foreign Origin. Russian Linguistics, 5, 75-90.

Wyjtwicz, M. (1984). Xarakteristika zaimstvovannyx iz anglijskogo jazyka imen suščestvitelnyx v russkom jazyke. Poznan: Adam Mickiewicz University Press.

Zemskaja, E. A., ed. (1973). Russkaja razgovornaja reč' [Spoken Russian]. Moscow: Nauka.

Železnova, M., \& Šengelija, V. (2005). Otkuda čto beretsja? Russkij Newsweek 17.

Retrieved November 7, 2006, from http://www.runewsweek.ru/theme/?tid=16\&rid=222.

Žirmunskij, V. Ž. (1925/1971). Vvedenie v metriku. Munich: W. Fink. 


\section{Notes}

1. This article does not focus specifically on the pedagogical challenges of combining two very different types of learners in one classroom, but my evolving approach has been to treat the class as two different groups meeting simultaneously. I prepare two syllabi, one for traditional L2 learners and the other for heritage learners. This approach tends not only to reassure the less verbally fluent students, but also to inform the heritage learners that they will not be able to coast through based on existing abilities. Practical challenges still need to be overcome in lesson planning and course design, but the complementary needs and abilities of the two groups can actually strengthen group and pair work in class sessions.

2. The word фрредятник [frendjatnik] obviously comes from the English word "friend", but the word льтылыбр [lytdybr], attributed to author Roman Leibov, has a much more interesting etymology. To recreate its origins, anyone with a standard Russian keyboard layout (not the transliterated keyboard layout popular in North America) can simply type the Cyrillic letters for the word дневник [dnevnik] ('diary') but without switching the keyboard from Latin to Cyrillic. The result is 'lytdybr', which entered internet circulation in Latin characters but was soon re-colonized by transliteration back into Cyrillic as 'лытдыбр.' Now the word finds itself with a Top 100 usage ranking among the most popular words and phrases in the Russian LiveJournal community, according to user "_a_c_e_"s data: (_a_c_e_, 2005).

3. The elision of vowels, especially in rapid speech, is one characteristic of colloquial speech that Russian linguists have studied for decades. Žirmunskij examined the phenomenon's implications for poetics in 1925 (Vvedenie v metriku), and more recently the study of conversational speech patterns has produced comprehensive analyses that explain, for example, the reduction or even disappearance of vowel and/or consonant sounds in specific phonetic contexts. See Zemskaja (1973), 43 ff.

4. This list does not include the many obscenities also found in the review. The use of nonstandard spelling is frequently but not always accompanied by defiant vulgarity that embraces expletives from Russian, English and other languages. The review in question is written by a reviewer who uses an English-language expletive as her/his username and is within a browser frame surrounded by links not just to other discussion forums on the site, but also to pornography sites and other dubious advertisers. The page also includes a warning to visitors that begins: Этот ресурс создан для настоящих падонков (standard spelling подонков [podonkov]) [Ètot resurs sozdan dlja nastojaščix padonkov] ('This resource has been created for real low-lifes.') (Udaff.com, 2005).

5. The post is one of hundreds in the forum (Nata, 2004). Russian speakers will be familiar with this particular argument. For non-Russian speakers, it is socioculturally, if not structurally, parallel to the dueling English variants 'Ukraine' and 'the Ukraine.' The use of 'na Vrkainu' for na Ukrainu ('to the Ukraine') and 'vna rodine' for na rodine (' in the homeland') are deliberate word plays combining the two prepositions under discussion. 
6. The standard spelling of this word is що [ščo].

7. Here, яд $[j a d]$ ('poison') is rendered in a way uncharacteristic of native-Russian words beginning with [j] but peculiar to a small number of foreign borrowings with this initial sound.

8. I include Smirnov's sample sentence here for those who are interested: Ва время акупацыи ыстонтсы убигали в леса и там прятались, а самые смелые инагда дажы шкодили памаленьку, ну там, абзавут рускава салдата изза дерева Даслом или фак паказывайут в карманеї [Va vremja akupacyi ystontsy ubigali v lesa i tam prjatalis', a samye smelye inagda day škodili pamalen'ku, nu tam, abzavut ruskava saldata izza dereva aslom ili fak pakazyvajut $v$ karmane] (Smirnov, 2005). ('During the occupation the Estonians ran away into the woods and hid there, and the bravest sometimes even taunted [them] a little, here and there calling a Russian soldier an ass from behind a tree or flipping them the bird inside their pocket.')

9. Numerous excellent collections of links are available; two of my favorites are the wellorganized set maintained by Benjamin Sher (n.d.) Sher's Russian Index and another by the University of Wisconsin's Center for Russia, East Europe, and Central Asia (CREECA) (n.d.)

10. Anyone who has visited Moscow in 2006 or 2007 may be surprised to learn that while the enormous Hotel Rossija has been reduced to a pile of rubble, the hotel's website is still fully functional. The next time I use this assignment, I will replace the Rossija site with one for another Moscow hotel such as the Metropol (Offcial'nyj sajt gostinicy Metropol', n.d.) or the Izmailovo (Gamma-del'ta, n.d.). Those looking for a site that has no Englishlanguage version will find this increasingly difficult, although some sites' English-language pages currently exist only as links to empty pages (e.g. Hotel Akademičeskaja (Gostinica Akademičeskaja, n.d.).

11. Television and film listings, along with a vast amount of other entertainment information, are available at the entertainment page of KM.ru (KM.ru afiša, n.d.)

12. After personally experiencing the disastrous results (including data loss and a completely immobilized operating system) of my own naive rambles through the Russian [DL] internet in the past, I now warn students to be sure that they use the most current network security features before embarking on any of these assignments. Since switching to the Firefox browser and activating the numerous additional security plug-ins that are available for Firefox, I have not had any problems.

13. I thank one of the $H L J$ anonymous reviewers for this suggestion. Spell checkers are available for a fee to supplement commercial programs like Word and WordPerfect, or at no cost for the freeware program OpenOffice (Sun Microsystems, n.d.). Spell check modules can be added once the main program has been installed. 